\title{
Analisis pengaruh tingkat pendidikan dan pertumbuhan ekonomi terhadap tingkat kemiskinan di Provinsi Jambi
}

\author{
*Nurhasanah; M. Syafri; Jaya Kusuma Edi \\ Prodi Ekonomi Pembangunan, Fakultas Ekonomi dan Bisnis, Universitas Jambi \\ *E-mail korespondensi: annahaja0@gmail.com
}

\begin{abstract}
Abstrack
The purpose of this research: (1) To know the development of education level and economic growth to the level of poverty in Jambi Province; (2) To know the influence of education level and economic growth to Poverty Level in Jambi Province. The method of analysis used in this study deskrptif analysis and quantitative analysis with the analysis tool is multiple linear regression. Data processing is done by using Microsoft Excel Software program and Eviews 8.0. The results of this study are the first overall development level of education (TP) during the period 2000-2016 on average increased by 0.64 percent. Economic growth in 2016 of 7.5 percent increase compared to the year 2015 of 5.9 percent. The four variables together significantly affect the poverty rate with the coefficient of TP of -0.080240, PE coefficient of -0.256608 percent. For the value of coefficient of determination (R2) of 0.614738 shows that TP and PE together affect the poverty rate of 61.47 while the rest of 38.53 percent explained by other variables not included in the model estimation.
\end{abstract}

Keywords: Poverty Level, Education Level, and Economic Growth.

\begin{abstract}
Abstrak
Tujuan dalam penelitian ini: (1) Untuk mengetahui perkembangan tingkat pendidikan dan pertumbuhan ekonomi terhadap tingkat kemiskinan di Provinsi Jambi; (2) Untuk mengetahui pengaruh tingkat pendidikan dan pertumbuhan ekonomi terhadap tingkat kemiskinan di Provinsi Jambi. Metode analisis yang digunakan dalam penelitian ini analisis deskrptif dan analisis kuantitatif dengan alat analisis yaitu regresi linear berganda. Pengolahan data dilakukan dengan menggunakan program Software Microsoft Excel dan Eviews 8.0. Adapun hasil penelitian ini yang pertama secara keseluruhan perkembangan Tingkat Pendidikan (TP) selama periode 2000-2016 ratarata meningkat sebesar 0,64 persen. Pertumbuhan ekonomi tahun 2016 sebesar 7,5 persen naik dibandingkan pada tahun 2015 yakni 5,9 persen. Keempat variabel secara bersama berpengaruh signifikan terhadap tingkat kemiskinan dengan koefesien TP sebesar -0.080240 , koefesien PE sebesar -0.256608 persen. Untuk nilai koefesien determinasi $\left(\mathrm{R}^{2}\right)$ sebesar 0.614738 menunjukan bahwa TP dan PE secara bersama-sama berpengaruh terhadap tingkat kemiskinan sebesar 61,47 sedangkan sisanya sebesar 38,53 persen dijelaskan oleh variabel lain yang tidak dimasukkan dalam model estimasi. Kata Kunci: Tingkat Kemiskinan, Tingkat Pendidikan, dan Pertumbuhan Ekonomi.
\end{abstract}

\section{PENDAHULUAN}

Pengertian kemiskinan umumnya selalu dikaitkan hanya dengan sektor ekonomi semata. Padahal kemiskinan bisa dilihat dari sisi sosial maupun budaya masyarakat. Pada prinsipnya kemiskinan menggambarkan kondisi ketiadaan kepemilikan dan 
rendahnya pendapatan, atau secara lebih rinci menggambarkan suatu kondisitidak dapat terpenuhinya kebutuhan dasar manusia, yaitu pangan, papan dan sandang. Beberapa definisi menggambarkan kondisi ketiadaan tersebut. Salah satunya adalah definisi kemiskinan yang digunakan BPS, yang menjelaskan kemiskinan sebagai ketidakmampuan individu dalam memenuhi kebutuhan dasar minimal untuk hidup layak (BPS dan Depsos,2002).

Kemiskinan merupakan masalah kompleks yang dipengaruhi oleh berbagai faktor yang saling berkaitan, antara lain tingkat pendapatan, pertumbuhan ekonomi, tingkat pengangguran, kesehatan, pendidikan, akses terhadap barang dan jasa serta lokasi lingkungan. Kemiskinan juga tidak lagi dipandang sebatas ketidakmampuan ekonomi. Menurut Hall dan Midgley, menyatakan kemiskinan dapat didefinisikan sebagai kondisi deprivasi materi dan sosial yang menyebabkan individu hidup di bawah standar kehidupan yang layak, atau kondisi dimana individu mengalami deprivasi relatif dibandingkan dengan individu yang lainnya dalam masyarakat.

Suparlan (1993), kemiskinan adalah tingkat rendah standar hidup, yaitu tingkat kekurangan materi dalam jumlah atau sekelompok orang yang dibandingkan dengan standar hidup yang berlaku dalam masyarakat yang bersangkutan.

Pengertian mengenai arti dari kemiskinan sangatlah beragam, keberagaman dalam definisi kemiskinan dikarenakan masalah tersebut telah merambat pada level multidimensional, artinya Kemiskinan berkaitan satu sama lain dengan berbagai macam dimensi kebutuhan manusia. Ketidakmampuan untuk memenuhistandar hidup minimum yang sesuai dengan tingkat kelayakan hidup dapat dikatakan sebagai kemiskinan (Todaro, 2006).

Kemiskinan berkaitan erat dengan masalah laju pertumbuhan penduduk yang kemudian menghasilkan pengangguran, ketimpangan sosial dalam distribusi pendapatan nasional maupun pembangunan, dan pendidikan yang menjadi modal utama untuk dapat bersaing didunia kerja. Di zaman sekarang untuk mendapatkan pendidikan yang berkualitas maka perlu diimbangi dengan biaya.Sehingga masyarakat yang ekonominya lemah tidak mampu untuk membayarnya. Akibatnya,pendidikan dan pengetahuan yang dimiliki di bawah standar. Bahkan banyak anak-anak yang tidak sekolah dan putus sekolah karena kemiskinan.

Menurut Sharp (Mudrajat Kuncoro, 2006) terdapat tiga faktor penyebab kemiskinan jika dipandang dari sisi ekonomi. Pertama, kemiskinan muncul karena adanya ketidaksamaan pola kepemilikan sumber daya yang menimbulkan distribusi pendapatan yang timpang. Penduduk miskin hanya memiliki sumberdaya yang terbatas dan kualitasnya rendah. Kedua, kemiskinan muncul akibat perbedaan dalam kualitas sumber daya manusia. Kualitas sumber daya manusia yang rendah berarti produktivitasnya rendah, yang pada gilirannya upahnya rendah.Rendahnya kualitas sumber daya manusia ini karena rendahnya pendidikan, nasib yang kurang beruntung, adanya diskriminasi atau keturunan. Ketiga kemiskinan muncul karena perbedaan akses dalam modal.

Di Provinsi Jambi kemiskinan masih menjadi salah satu masalah besar yang sampai saat ini masih harus ditanggulangi agar tidak terjadi kenaikan setiap tahunnya.Kemiskinan merupakan salah satu dari issue strategi yang mendapat priorita suntuk penanganan pada setiap tahapan pelaksanaannya. Stabilitas ekonomi dalam perekonomian wilayah Provinsi Jambi.

Pendidikan merupakan sesuatu yang sangat penting bagi suatu bangsa dengan bekal pendidikan, suatu bangsa dapat bangkit dari keterpurukannya dan mencapai kejayaannya. Namun, tidak semua orang mampu, orang Indonesia mampu mengeyam 
bangku sekolah.Pendidikan dalam kamus besar Bahasa Indonesia (2008) yaitu proses perubahan sikap dan tata laku seseorang atau sekelompok orang dalam usaha mendewasakan manusia melalui upaya pengajaran dan pelatihan. Di dalamUndangUndang Republik Indonesia pasal 1 Nomor 20 Tahun 2003 tentang pendidikan Nasional, pengertian pendidikan adalah usaha sadar dan terencana untuk mewujudkan suasana belajar dan proses pembelajaran agar peserta didik secara aktif mengembangkan potensi dirinya untuk memiliki kekuatan spiritual keagamaan, pengendalian diri, kepribadian, kecerdasan, akhlak mulia, serta keterampilan yang diperlukan dirinya, masyarakat, bangsa dan negara (Sisdiknas, 2003).

Branata (1988) mengungkapkan bahwa Pendidikan ialah usaha yang sengaja diadakan, baik langsung maupun secara tidak langsung, untuk membantu anak dalam perkembangannya mencapai kedewasaan. Pendapat diatas seajalan dengan pendapat Purwanto (1987) yang menyatakan bahwa Pendidikan adalah pimpinan yang diberikan dengan sengaja oleh orang dewasa kepada anak-anak, dalam pertumbuhannya (jasmani dan rohani) agar berguna bagi diri sendiri dan bagi masyarakat.

Menurut Mulyadi (2008), pendidikan merupakan salah satu bentuk investasi dalam sumber daya manusia, sebab pendidikan di harapkan dapat mengatasi keterbelakangan ekonomi lewat efeknya pada peningkatan manusia dan motivasi manusia untuk berprestasi dan akhirnya akan meningkatkan pendapatanya sehingga mampu meningkatkan taraf hidupnya.

Pendidikan sering diartikan sebagai usaha manusia untuk membina kepribadiannya sesuai dengan nilai-nilai di dalam masyarakat dan kebudayaan. Selanjutnya, pendidikan diartikan sebagai usaha yang dijalankan oleh seseorang atau kelompok orang lain agar menjadi dewasa atau mencapai tingkat hidup atau penghidupan yang lebih tinggi dalam arti mental (Hasbullah, 2008).

Pertumbuhan ekonomi merupakan suatu masalah panjang yang harus dilakukan oleh setiap negara.Dimana sangat diharapkan terjadinya pertumbuhan ekonomi tersebut.Pertumbuhan ekonomi yang pesat merupakan fenomena penting yang dialami dunia semenjak dua abad belakangan ini. Menurut Prof. Simon Kuznet, pertumbuhan ekonomi sebagai kenaikan jangka panjang dalam kemampuan suatu negara untuk menyediakan semakin banyak jenis barang-barang ekonomi kepada penduduknya, kemampuan ini tumbuh sesuai dengan kemajuan teknologinya dan penyesuaian kelembagaan dan ideologis yang diperlukan.

Menurut Budiono (1994), pertumbuhan ekonomi adalah suatu proses pertumbuhan output perkapita jangk apanjang yang terjadi apabila ada kecenderungan (output perkapita untuk naik) yang bersumber dari proses intern perekonomian tersebut (kekuatan yang berada dalam perekonomian itu sendiri), bukan berasal dari luar dan bersifat self generating, yang berarti bahwa proses pertumbuhan itu sendiri menghasilkan suatu kekuatan atau momentum bagi kelanjutan pertumbuhan tersebut dalam periode-periode selanjutnya.

Menurut M.P. Todaro, pertumbuhan ekonomi sebagai suatu proses yang mantap dimana kapasitas produksi dari suatu perekonomian meningkat sepanjang waktu untuk menghasilkan tingkat pendapatan nasional yang semakin besar. Sedangkan Menurut SadonoSukirno pertumbuhan ekonomi merupakan perubahan tingkat kegiatan ekonomi yang berlaku dari tahun ketahun. Sehingga untuk mengetahuinya harus diadakan perbandingan pendapatan nasional dari tahun ketahun, yang dikenal denganl aju pertumbuhan ekonomi.

Sukirno (2000) berpendapat bahwa pertumbuhan ekonomi merupakan perubahan tingkat kegiatan ekonomi yang berlaku dari tahun ketahun. Sehingga untuk 
mengetahuinya harus diadakan perbandingan pendapatan nasional dari tahun ketahun, yang dikenal dengan laju pertumbuhan ekonomi.

Sedangkan menurut Esmara, laju pertumbuhan ekonomi adalah proses kenaikan output dalam jangka panjang. Dalam lintas ekonomi regional pengukuran laju pertumbuhan ekonomi secara sektoral dapat digunakan data PDRB. Data ini dapat memberikan gambaran yang jelas tentang tinggi rendahnya pertumbuhan ekonomi suatu negara atau wilayah di berbagai sektor.

Menurut Arsyad (2008), pertumbuhan ekonomi diartikan sebagai kenaikan Produk Domesti Bruto tanpa memandang apakah kenaikan tersebut lebih besar atau lebih kecil dari tingkat pertumbuhan penduduk atau apakah struktur ekonomi terjadi atau tidak. Pertumbuhan ekonomi merupakan salah satu indikator penting guna menganalisis pembangunan ekonomi yang terjadi suatu negara.

Pada tahun 2000 tingkat pendidikanProvinsi Jambi sebesar 226,15\% dan pada tahun 2007 naikmenjadi 247,61\%. Pada tahun 2016 terus meningkat menjadi 289,43\%. Pada tahun 2000 pertumbuhan ekonomi Provinsi Jambi tumbuh sebesar9,7\% dan pada tahun 2007 turun menjadi 6,8\%. Pada tahun 2016 mengalami peningkatan sebesar 7,5\%. Dan pada tahun 2000 tingkat kemiskinan mencapai12,45\%, pada tahun 2007 dan 2016 mengalami penurunan mencapai yaitu 10,27\% dan 2016 sebesar 8,37\%. Tujuan penelitian ini untuk mengetahui dan menganalisis: 1) Perkembangan tingkat pendidikan dan pertumbuhan ekonomi terhadap tingkat kemiskinan; 2) Pengaruh tingkat pendidikan dan pertumbuhan ekonomi terhadap tingkat kemiskinan.

\section{METODE}

Jenis data yang digunakan dalam penelitian ini adalah data sekunder yang disajikan dalam bentuk data tahunan atau berkala (time Series) selama 17 tahun dari tahun 2000-2016 yang meliputi: a) Tingkat PendidikanProvinsiJambi 2000-2016; b) Pertumbuhan EkonomiProvinsi Jambi 2000-2016; c) Tingkat KemiskinanProvinsi Jambi 2000-2016. Penelitian ini menggunakan metode analisis deskriptif dan kuantitatif. Untuk menganalisis perkembangan tingkat pendidikan dengan Angka Partisipasi Sekolah (APS) di Provinsi Jambi dapat dihitung dengan rumus sebagai berikut:

$$
\begin{aligned}
& \operatorname{APS}(7-12)=\left\{\left(\frac{J p 7-12 \text { tahun }}{J p 7-12 \text { tahun }} \times 100 \%\right)\right\} \\
& \operatorname{APS}(13-15)=\left\{\left(\frac{J p 13-15 \text { tahun }}{J p 13-15 \text { tahun }} \times 100 \%\right)\right\} \\
& \operatorname{APS}(16-18)=\left\{\left(\frac{J p 16-18 \text { tahun }}{J p 16-18 \text { tahun }} \times 100 \%\right)\right\} \\
& \operatorname{APS}(19-24)=\left\{\left(\frac{J p 19-24 \text { tahun }}{J p 19-24 \text { tahun }} \times 100 \%\right)\right\}
\end{aligned}
$$

Dimana:

Aps : Angka partisipasi sekolah

Jp : Jumlah Penduduk

Untuk menganalisis pengaruh tingkat pendidikan dan pertumbuhan ekonomi terhadap tingkat kemiskinan digunakan alat analisis regresi linier berganda dalam bentuk rumus persamaan berikut ini:

Persamaan dasar ekonometrik:

$$
\mathrm{Y}=\mathrm{a}+b_{1} x_{1}+b_{2} x_{2}+\ldots \ldots b_{n} x_{n}
$$


Dimana:

$$
\begin{array}{ll}
\mathrm{Y} & =\text { Variabeldependen( nilai yang diprediksikan ) } \\
\mathrm{x}_{1} \text { dan } \mathrm{x}_{2} & =\text { Variabelindependen } \\
\mathrm{a} & \left.=\text { Konstanta (nilai } \mathrm{Y} \text { apabila } x_{1}, x_{2} \ldots \ldots x_{n}=0\right) \\
\mathrm{b} & =\text { Koefisienregresi (nilaipeningkatan) }
\end{array}
$$

Persamaan dasar regresi linear berganda sebagai berikut:

$\mathrm{Y}=\beta_{0}-\beta_{1} X_{1}-\beta_{2} X_{2}-\varepsilon$

Dimana:

$\mathrm{Y} \quad=$ TingkatKemiskinan

$\beta_{0} \quad=$ Konstanta

$\beta_{1}, \beta_{2}=$ KoefisienRegresi

$X_{1} \quad=$ Tingkat Pendidikan

$X_{2}=$ PertumbuhanEkonomi

$\varepsilon \quad=$ Standar Eror

Setelah dilakukan perhitungan dengan menggunakan alat analisis linier berganda, maka dilakukan pengujian hipotesis yaitu uji $\mathrm{F}$, uji $\mathrm{t}$ dan koefisien determinasi. Pengujian asumsi klasik menjadi suatu hal yang penting untuk melihat penyimpangan-penyimpangan yang terjadi pada suatu model, maka pada penelitian ini dilakukan pengujian asumsi klasik yaitu uji multikolinearitas. Uji autokorelasi menggunakan uji LM dan uji heterokedasitas menggunakan white (Junaidi, 2015).

\section{HASIL DAN PEMBAHASAN}

\section{Perkembangan tingkat pendidikan di Provinsi Jambi}

Angka Partisipasi Sekolah (APS) merupakan ukuran daya serap lembaga pendidikan terhadap penduduk usia sekolah.Semakin tinggi angka partisipasi sekolah semakin besar jumlah penduduk yang berkesempatan melanjutkan pendidikan.

Tabel 1. Perkembangan tingkat pendidikan Provinsi Jambi Tahun 2000-2016

\begin{tabular}{ccc}
\hline Tahun & Tingkat Pendidikan $\mathbf{\%})$ & Perkembangan $(\boldsymbol{\%})$ \\
\hline 2000 & 226,15 & - \\
2001 & 218,94 & 3,29 \\
2002 & 234,23 & 3,57 \\
2003 & 243,85 & 4,10 \\
2004 & 248,04 & 1,71 \\
2005 & 239,01 & $-3,64$ \\
2006 & 245,12 & 2,55 \\
2007 & 247,61 & 1,01 \\
2008 & 247,31 & $-0,12$ \\
2009 & 250,00 & 1,08 \\
2010 & 252,75 & 1,1 \\
2011 & 261,18 & 3,33 \\
2012 & 263,80 & 1,00 \\
2013 & 273,71 & 3,75 \\
2014 & 286,85 & 4,80 \\
2015 & 287,58 & 0,25 \\
2016 & 289,43 & 0,64 \\
\hline
\end{tabular}


Sumber: Badan Pusat Statistik Provinsi Jambi, 2016 (diolah).

Berdasarkan data yang diperoleh dari Badan Pusat Statistik Provinsi Jambi yang tertera pada tabel di bawah ini, angka tingkat pendidikan Provinsi Jambi pada tahun 2000-2016 tingkat pendidikan di Provinsi Jambi secara umum mengalami fluktuasi. Pada tahun 2000 APS sebesar 226,15 persen kemudian APS meningkat pada tahun 2014 sebesar 286,85 persen dan terus meningkat pada tahun 2016 APS sebesar 289,43 persen. Perkembangan tingkat pendidikan pada tahun 2000-2016 mengalami peningkatan pada tahun 2010 perkembangan tingkat pendidikan sebesar 1,1 persen. Pada tahun 2015 mengalami penurunan sebesar 0,25 persen. Pada tahun 2016 mengalami peningkatan sebesar 0,64 persen. Dengan rata- rata perkembangan sebesar 1,85 persen. Data ini dapat dilihat pada tabel 1 .

\section{Perkembangan pertumbuhan ekonomi di Provinsi Jambi}

Pertumbuhan ekonomi adalah kenaikan kapasitas dalam jangka panjang dari negara yang bersangkutan untuk menyediakan berbagai barang ekonomi kepada penduduknya.Pertumbuhan ekonomi pada periode 2000-2016, yang paling tinggi dicapai pada tahun 2011 yakni 8,6\%. hal mana dimungkinkan oleh harga pasar komoditi yang dihasilkan oleh Provinsi Jambi pada banyaknya perkebunan karet dan kelapa sawit.

Tabel 2. Perkembangan pertumbuhan ekonomi Provinsi Jambi Tahun 2000-2016

\begin{tabular}{ccc}
\hline Tahun & Pertumbuhan Ekonomi $(\%)$ & Perkembangan $\mathbf{( \% )}$ \\
\hline 2000 & 9,7 & - \\
2001 & 8,8 & $-9,27$ \\
2002 & 8,1 & $-7,95$ \\
2003 & 7,5 & $-7,40$ \\
2004 & 5,4 & -28 \\
2005 & 5,6 & 3,70 \\
2006 & 5,9 & 5,35 \\
2007 & 6,8 & 15,25 \\
2008 & 7,2 & 5,88 \\
2009 & 6,4 & $-11,11$ \\
2010 & 7,3 & 14,06 \\
2011 & 8,6 & 17,80 \\
2012 & 7,4 & $-13,48$ \\
2013 & 4,9 & $-34,13$ \\
2014 & 4,7 & $-4,08$ \\
2015 & 5,9 & 25,53 \\
2016 & 7,5 & 27,11 \\
\hline & Rata-rata & $\mathbf{- 0 , 8 9}$
\end{tabular}

Sumber: Badan Pusat Statistik Provinsi Jambi, 2016 (diolah).

\section{Perkembangan tingkat kemiskinan di Provinsi Jambi}

Masalah kemiskinan bagi Provinsi Jambi merupakan isu strategisdan mendapatkan prioritas utama untuk ditangani. Hal ini terbukti dalam Rencana Strategis (Renstra) Jambi dan di dalam Rencana Pembangunan Jangka Panjang Daerah (RPJPD) Jambi tahun 2000-2016. Upaya penanggulangan kemiskinan telah diakukan melalui berbagai strategi. Secara langsung diwujudkan dalam bentuk pemberian dana bantuan 
stimultan sebagai modal usaha kegiatan ekonomi produktif dan bantuan sosial. Bantuan secara tidak langsung dilakukan melalui penyediaan sarana dan prasarana pendukung kegiatan sosial ekonomi dan pemberdayaan masyarakat. Jika sudah dapat meningkatkan taraf hidup masyarakat yang relatif rendah. Perkembangan tingkat kemiskinan Provinsi Jambi dapat dilihat pada tabel 3 berikut:

Tabel 3. Perkembangan tingkat kemiskinan Provinsi Jambi Tahun 2000-2016

\begin{tabular}{cccc}
\hline Tahun & $\begin{array}{c}\text { Penduduk Miskin } \\
\text { (Jiwa) }\end{array}$ & $\begin{array}{c}\text { Tingkat Kemiskinan } \\
(\boldsymbol{\%})\end{array}$ & $\begin{array}{c}\text { Perkembangan } \\
(\boldsymbol{\%})\end{array}$ \\
\hline 2000 & 356.380 & 12,45 & - \\
2001 & 376.618 & 12,46 & 0,08 \\
2002 & 188.520 & 12,70 & 1,92 \\
2003 & 192.711 & 12,74 & 0,31 \\
2004 & 194.329 & 12,45 & $-2,27$ \\
2005 & 215.245 & 11,88 & $-4,57$ \\
2006 & 232.561 & 11,37 & $-4,29$ \\
2007 & 258.580 & 10,27 & $-9,67$ \\
2008 & 261.300 & 9,28 & $-9,63$ \\
2009 & 245.000 & 8,55 & $-7,86$ \\
2010 & 260.446 & 8,40 & $-1,75$ \\
2011 & 251.789 & 7,90 & $-5,95$ \\
2012 & 270.182 & 8,29 & 4,93 \\
2013 & 302.900 & 8,42 & 1,56 \\
2014 & 281.720 & 8,30 & $-1,42$ \\
2015 & 300.710 & 8,86 & 6,74 \\
2016 & 289.813 & 8,37 & $-5,53$ \\
\hline & Rata-rata & & $\mathbf{- 5 , 5 3}$ \\
\hline
\end{tabular}

Sumber: Badan Pusat Statistik Provinsi Jambi, 2016 (diolah).

Kondisi kemiskinan di Provinsi Jambi tergolong rendah dibandingkan dengan kemiskinan nasional, jumlah penduduk miskin tahun 2000 tercatat sekitar 356.380 jiwa. Sementara persentase kemiskinan tahun 2000 sebesar 12,45 persen. Pada tahun 2005 perkembangan tingkat kemiskinan di Provinsi Jambi menurun menjadi -4,57 persen dengan persentase tingkat kemiskinan sebesar 11,88 persen. Kemudian jumlah penduduk miskin Provinsi Jambi dari tahun ke tahun terus menurun meskipun tidak terlalu banyak hingga pada tahun 2014 jumlah penduduk miskin di Provinsi Jambi sebesar 281.720 jiwa dengan tingkat kemiskinan mencapai 8,30 persen dan perkembangan tingkat kemiskinan Provinsi Jambi sebesar $-1,42$ persen. pada tahun 2015 kemiskinan terus meningkat sebesar 8,86 persen dengan perkembangan tingkat kemiskinan sebesar 6,74 persen. Pada tahun 2016 kemiskinan mengalami penurunan dengan jumlah penduduk sebesar 290,81 dan tingkat kemiskinan sebesar 8,37 persen dengan perkembangan sebesar $-5,53$ persen.

\section{Pengaruh tingkat pendidikan,pertumbuhan ekonomi terhadap tingkat kemiskinan di Provinsi Jambi.}

Sesuai dengan permasalahan dan perumusan model yang telah dikemukakan, maka analisis statistik yang dilakukan untuk melihat analisis pengaruh tingkat pendidikan dan pertumbuhan ekonomi terhadap tingkat kemiskinan ditunjukkan oleh hasil estimasi regresi berganda di bawah ini: 
Koefesien regresi variable Tingkat Pendidikan (TP) bernilai negatif sebesar 0.080240 yang memberikan arti bahwa setiap peningkatan tingkat pendidikan 1 persen maka Tingkat Kemiskinan di Provinsi Jambi akan menurun sebesar 0,8 persen dengan asumsi pertumbuhan ekonomi tidak berubah. Tingkat pendidikan (TP) memberikan pengaruh yang negatif dan signifikan terhadap tingkat kemiskinan di Provinsi Jambi. Tingkat Pendidikan (TP) terhadap tingkat kemiskinan berada pada probabilitas sebesar 0.0005 lebih kecil dari $\alpha=0,05$ (5 persen), artinya Tingkat Pendidikan (TP) berpengaruh dan bersifat negatif terhadap tingkat kemiskinan di provinsi jambi

Tabel 4. Hasil perhitungan model persamaan regresi linear berganda

\begin{tabular}{lrlrr}
\hline \hline \multicolumn{1}{c}{ Variable } & Coefficient & \multicolumn{1}{c}{ Std. Error } & t-Statistic & \multicolumn{1}{c}{ Prob. } \\
\hline \multicolumn{1}{c}{ C } & 32.30438 & 5.741977 & 5.626004 & 0.0001 \\
TP & -0.080240 & 0.017989 & -4.460499 & 0.0005 \\
PE & -0.256608 & 0.264768 & -0.969180 & 0.3489 \\
\hline \hline R-squared & 0.614738 & Mean dependent var & 10.15824 \\
Adjusted R-squared & 0.559701 & S.D. dependent var & 1.932787 \\
S.E. of regression & 1.282501 & Akaike info criterion & 3.494287 \\
Sum squared resid & 23.02733 & Schwarz criterion & 3.641324 \\
Log likelihood & -26.70144 & Hannan-Quinn criter. & 3.508903 \\
F-statistic & 11.16947 & Durbin-Watson stat & 0.368121 \\
Prob(F-statistic) & 0.001260 & & \\
\hline \hline
\end{tabular}

Sumber: Data diolah, 2019

Koefesien regresi variabel Pertumbuhan Ekonomi bernilai sebesar -0.256608 yang memberikan arti bahwa setiap peningkatan pertumbuhan ekonomi 1 persen maka Tingkat Kemiskinan di Provinsi Jambi akan menurun sebesar 0,25 persen. Dengan asumsi Tingkat pendidikan tidak berubah. Pertumbuhan ekonomi memberikan pengaruh yang negatif dan tidak signifikan terhadap tingkat kemiskinan di Provinsi Jambi. Hasil dari tidak signifikan pertumbuhan ekonomi terhadap tingkat kemiskinan ini terlihat dari probabilitasnya sebesar 0.3489 lebih besar dari $\alpha=0,05$ (5\%), maka Pertumbuhan ekonomi tidak berpengaruh terhadap tingkat kemiskinan di Provinsi Jambi.

\section{Koefesien Determinasi $\left(R^{2}\right)$}

Nilai $R^{2}$ menunjukan seberapa besar proporsi variable bebas terhadap variabel terikat. Hasil regresi dapat dilihat nilai $R^{2}$ sebesar 0.614738 (61,47\%). Artinya proporsi variable tingkat pendidikan dan pertumbuhan ekonomi di Provinsi Jambisebesar 61,47 $\%$ sedangkan sisanya $38,53 \%$ di pengaruhi oleh variable lain yang tidak termasuk dalam penelitian ini.

\section{Uji F Statistik}

Hasil regresi menunjukan nilai $F_{\text {hitung }}$ sebesar 11.16947 dengan tingkat kepercayaan $95 \% \alpha=5 \%$ di peroleh nilai $F_{\text {tabel }}$ sebesar 3,49. Hasil regresi menunjukan $F_{\text {hitung }}>F_{\text {tabel }}$ maka Ho ditolak dan Ha diterima yang artinya memiliki pengaruh yang signifikan antara variabel bebas terhadap variabel terikat. 


\section{KESIMPULAN DAN SARAN \\ Kesimpulan}

Dari hasil penelitian secara keseluruhan perkembangan Tingkat Pendidikan (TP) selama periode 2000-2016 rata-rata meningkat sebesar 0,64 persen. Pertumbuhan ekonomi tahun 2016 sebesar 7,5 persen naik dibandingkan pada tahun 2015 yakni 5,9 persen.

\section{Saran}

Dalam rangka mengentaskan kemiskinan di Indonesia, pemerintah perlu memperhatikan pertumbuhan ekonomi. Pertumbuhan ekonomi yang meningkat akan menurunkan tingkat kemiskinan. Apabila pertumbuhan ekonomi mengalami peningkatan maka pendapatan per kapita masyarakat juga bertambah sehingga akan mengakibatkan peningkatan kesejahteraan masyarakat untuk mengurangi kemiskinan.

Peran pemerintah harus ditingkatkan dalam rangka peningkatan pendidikan karena bahwasannya anak-anak merupakan investasi masa depan sebuah bangsa. Wajar saja ketika banyak orang menyerukan bahwa anak adalah bibit-bibit atau tunas yang harus diperhatikan dan dirawat dengan baik. Agar kualitas pendidikan di Indonesia dapat meningkat, perlu adanya kerja sama dari berbagai pihak, baik itu dari pemerintah maupun dari masyarakat sebagai pelaku dan penikmat pendidikan. Peran serta masyarakat dalam kemajuan kualitas pendidikan di negara ini sangat diharapkan agar tercipta suatu hubungan timbal balik yang baik antara pemerintah dan masyarakat.

\section{DAFTAR PUSTAKA}

Arsyad. (2008). Ekonomi mikro. BPFE Universitas Gajah Mada: Yogyakarta.

Badan Pusat Statistik (BPS). (2010). Kemiskinan 2010. Badan Pusat Statistik: Jambi. Boediono. (2017). Ekonomi Mikro. Fakultas Ekonomi dan Bisnis UGM: Yogyakarta. Hermanto, Siregar dan Dwi Wahyuniarti (2006): Dampak Pertumbuhan Ekonomi Terhadap Penurunan Jumlah Penduduk Miskin. Skripsi IPB: Bogor.

Gujarati, Damodar N. (2006). Dasar-Dasar Ekonometrika Jilid 1 dan 2, Edisi ketiga, Erlangga: Jakarta.

Kuncoro, Mudrajat. (1997). Ekonomi Pembangunan Teori, Masalah dan kebijakan. UPP AMP YKPN: Yogyakarta.

Nosa Putra Efry. (2013). Analisis Pengaruh Pertumbuhan Ekonomi dan pengangguran Terhadap Kemiskinan (Studi Komperatif Provinsi Jambi dan Indonesia Periode 2000-2011). Skripsi, Fakultas Ekonomi Universitas Jambi: Jambi.

Sukirno,Sadodo.( 2000). Makroekonomi Modern. PT Raja Drafindo Persada: Jakarta.

Suparlan, Parsudi. (1993). Kemiskinan DiPerkotaan. Cetakan Kedua. Yayasan Obor Indonesia: Jakarta.

Todaro Michael. (1994). Ekonomi di Dunia ketiga edisi kedua. Erlangga: Jakarta. 